\title{
Article \\ Differences in Soil Physicochemical Properties in Different-Aged Pinus massoniana Plantations in Southwest China
}

\author{
Xiaoai Yin ${ }^{1}$, Longshan Zhao ${ }^{1,2,3, * \mathbb{D}}$, Qian Fang ${ }^{1}$ and Guijie Ding ${ }^{1}$ \\ 1 College of Forestry, Guizhou University, Guiyang 550025, China; xiaoaiyin2021@163.com (X.Y.); \\ fangqian1221@163.com (Q.F.); gjdinggzu@126.com (G.D.) \\ 2 Research Institute of Forestry, Chinese Academy of Forestry, Beijing 100091, China \\ 3 Research Centre for Soil Erosion \& Eco-Restoration Sciences, Guizhou University, Guiyang 550025, China \\ * Correspondence: longshanzh@163.com; Tel./Fax: +86-187-9870-0582
}

check for

updates

Citation: Yin, X.; Zhao, L.; Fang, Q.; Ding, G. Differences in Soil Physicochemical Properties in Different-Aged Pinus massoniana Plantations in Southwest China. Forests 2021, 12, 987. https:/ / doi.org/10.3390/f12080987

Received: 16 June 2021

Accepted: 21 July 2021

Published: 26 July 2021

Publisher's Note: MDPI stays neutral with regard to jurisdictional claims in published maps and institutional affiliations.

Copyright: (c) 2021 by the authors. Licensee MDPI, Basel, Switzerland. This article is an open access article distributed under the terms and conditions of the Creative Commons Attribution (CC BY) license (https:// creativecommons.org/licenses/by/ $4.0 /)$.

\begin{abstract}
With increasing age, plants will cause changes in soil physicochemical properties. The objective of this study was to investigate differences in the soil physicochemical properties in different-aged Masson pine forest plantations (i.e., 10, 20, 40, and 60 years old). Soil samples were collected in a pure Masson pine forest plantation in Southwest China. The soil determination indexes included organic carbon, nitrogen, phosphorus and potassium contents, water content, bulk density, and $\mathrm{pH}$. The soil $\mathrm{pH}$ of a 20-year-old forest was significantly $(p<0.05)$ higher than that of a 10, 40, and 60-year-old forest. In addition, soil-available phosphorus in a 60-year-old forest was significantly $(p<0.05)$ higher than that in the other three age forest groups. With increasing forest age, available phosphorus increased, while available nitrogen decreased at 20 years old and then increased at 40 years old. There was a significant positive correlation $(p<0.05)$ between total nitrogen and available potassium; no significant correlation $(p>0.05)$ between total phosphorus and total potassium, organic carbon, bulk density, and $\mathrm{pH}$; and a significant negative correlation $(p<0.05)$ between available phosphorus and the water content. The availability and utilization efficiency of soil nutrients in young forests were higher than those in old forests and the intermediate forest age was an important time point that affected the soil properties. To improve the availability of soil nutrients and ensure the sustainable utilization of soil resources, it is necessary to increase the input of nitrogen and especially phosphorus. More attention should be given to the phytochemometric response with respect to the age of plantations.
\end{abstract}

Keywords: soil quality; forest age; soil nutrient cycle; planted forest

\section{Introduction}

Forest soil quality such as water and nutrient storage is important to maintain the growth of forests and is critical for the mineralization and fixation of nutrients [1]. Soil quality is directly related to the growth and sustainable development of plantations. Currently, the expansion of fast-growing tree plantations is a worldwide process and plantations play an increasingly important role in forestry construction and ecological construction. Negative and positive effects of afforestation were found for soil nutrients in different studies depending on local conditions [2-4]. In the natural environment with the passage of time, the heterogeneity of understory soil quality is enhanced and these differences are usually due to differences in climate, land use history [5], soil texture, and so on, in addition to management-related factors such as planting age and tending measures [6].

Previous studies have suggested that forest mismanagement affects the effectiveness of soil nutrients that will lead to soil degradation and hence influence forest health. For example, the interaction between soil acidification caused by fertilization and the long-term accumulation of organic matter affected soil microbial activity and enzyme activity [7]. The 
change in soil quality is affected by the increase in forest age. An increase in forest age will lead to a change in the comprehensive score of the soil quality and forest age also has an important effect on soil acidification [8,9]. In other words, with an increase in forest age, if reasonable management measures are not implemented in a timely manner, it will affect the sustainable use of forest soil.

Soil nutrient availability is one of the most direct indicators to evaluate soil quality. Among the indicators, the ratios of carbon, nitrogen, and phosphorus (C:N, C:P, and N:P) are referred to as ecological chemometrics (EST). EST provides a new method to predict the recycling of soil nutrients $[10,11]$. An increase in the total nitrogen content in forest soil helps to improve the availability of soil nutrients, thus changing the soil stoichiometric value [12]. Changes in plantation age have a strong influence on soil nutrients and the stoichiometric value [13]. Tree demand for soil nutrients differs among trees of different ages. For example, the growth of middle-aged larch forests (20 years) was reported to be limited by $\mathrm{N}$, the growth of near-mature larch forests (37 years) was limited by phosphorus (P), and the growth of young larch forests (14 years) did not indicate a soil nutrient deficiency $[14,15]$.

At present, research results on the characteristics of soil nutrient changes with the age of plantations vary with tree species, regions, and soil conditions. For example, Lucas Borja et al. [16] studied the soil nutrient characteristics of different-aged pine forests at five different locations in Spain and reported that age had a significant impact on most of the analytical elements, and nutrients tended to occur in the soil rather than to accumulate in other components. Jonard et al. [17] conducted long-term monitoring of the changes in soil organic carbon (SOC) in French forests and the results demonstrated that the SOC accumulation rate was linear in response to forest age and was affected by the stand structure. Leuschner et al. [18] found that the age of beech forests in northern Germany was a key factor in soil carbon (c) storage potential and nutrient storage, and the continuity of forest cover may be related to tree age. In addition, Bautista-Cruz et al. [19] studied the ecological significance of forest age in the functional interpretation of the selected soil quality index (SQI) in the Tropical Mountain Cloud Forest (TMCF) in Mexico and the results demonstrated that soil organic carbon, $\mathrm{pH}$, and available phosphorus were important evaluation indicators. These findings indicate that the influence of forest age on soil has received attention from researchers worldwide. Unfortunately, the effects of tree growth cycles on soil stoichiometry and soil quality are often overlooked especially in plantations that lack nutrient management [20,21].

Masson pine (Pinus massoniana Lamb.) is a typical coniferous tree species. Studies have shown that coniferous forests are more vulnerable to soil degradation than other tree species such as broadleaf forests [8]. The growth cycle of Masson pine is long and its growth is easily affected by changes in the environment, climate, and time. According to Corwin et al. [22], a long-term planting pattern will lead to soil nutrient loss and soil quality decline. The contents of soil carbon, nitrogen, and phosphorus were reported to decrease with increasing plantation age and the soil fertility decreased gradually [23]. Justine et al. [24] demonstrated that the soil carbon-nitrogen ratio (TOC/TN) decreased significantly with increasing forest age. At present, the research data on the relationship between the age of Masson pine trees and soil quality are insufficient and most of the studies do not have sufficient soil sampling depths. As an important economic timber forest species worldwide, Masson pine has a large distribution area. Therefore, it is urgent to systematically discuss the influence of Masson pine forest age on soil quality, notably very important for understanding the soil cycle process of a specific forest.

The objectives of this study were to investigate the soil physicochemical properties in Masson pine plantations of different ages and to analyse the effect of plantation age on soil quality in Southwest China. To achieve this aim, four forest ages (i.e., 10, 20, 40, and 60 years) were selected and soil samples were collected at six soil depths (i.e., 0-10, $10-20,20-30,30-40,40-50$, and 50-60 cm). The results provide a reference for Masson 
pine plantation management (e.g., forest tending and stand transformation) and a deeper understanding of the forest soil nutrient characteristics.

\section{Research Area and Research Method}

\subsection{Study Area}

This study was conducted in a pure Masson pine plantation $\left(106^{\circ} 44^{\prime} 20^{\prime \prime} \mathrm{E}, 26^{\circ} 29^{\prime} 35^{\prime \prime} \mathrm{N}\right)$ in the Nanming District Forestry Research Institute, Guiyang City, Southwest China, that belongs to the Central Asian hot monsoon climate. The average annual temperature is 15.2 ${ }^{\circ} \mathrm{C}$ and the average annual rainfall is $1199 \mathrm{~mm}$. The soil type is aluminous luvisols and the parent material is sandstone. Correlative tending measures were adopted in different growth periods of Masson pine. In the tending process of the planting year, only the grass was cut but the soil was not loosened and was properly cultivated after the seedlings were levelled. After 20 years, thinning intensity was controlled at 30\% and canopy density of stand was controlled at about 70\% [25] (Figure 1).

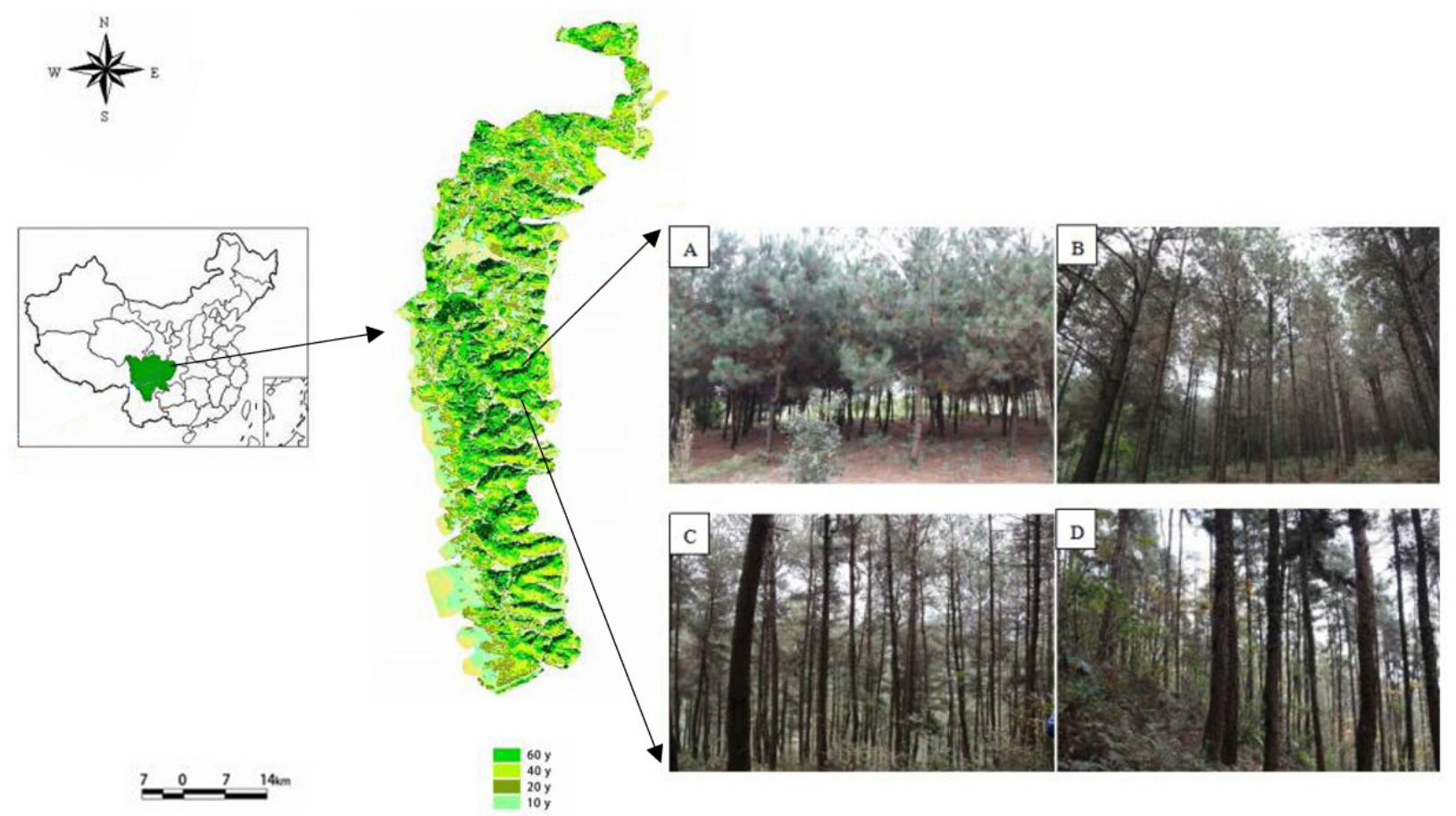

Figure 1. Test plot (the study area is located in Southwest China; 10 years, 20 years, 40 years, and 60 years represent a Masson Pine forest age of 10, 20, 40, and 60 years old, respectively; (A-D) are the respective 10, 20, 40, and 60-year-old Masson pine plantations).

\subsection{Experimental Design}

From May to November 2019, representative forest ages (10, 20, 40, 60 years) with consistent site conditions of Masson pine plantations were selected as the test sample sites in the study area (see Figure 1 for the specific sample sites). Each sample size was $20 \mathrm{~m} \times 20 \mathrm{~m}$ and samples were collected in triplicates. The general condition of the sample plots is shown in Table 1. Samples were collected from the 0-10, 10-20, 20-30, 30-40, $40-50$, and 50-60 cm soil layers using a 5-point sampling method. Five samples from the same soil layer were mixed evenly and $1 \mathrm{~kg}$ soil was removed according to the quartering method, rapidly transported to the laboratory for natural air drying, and the DBH (DBH) of all Masson pine in various formulae were determined. The experiment was conducted throughout a single growing season that allowed us to determine the seasonal variations in the soil nutrients. 
Table 1. Basic information of the sample plots.

\begin{tabular}{ccccccc}
\hline Forest Age (Years) & Longitude & Latitude & Elevation (m) & $\begin{array}{c}\text { Diameter } \\
\text { at Breast } \\
\text { Height (cm) }\end{array}$ & $\begin{array}{c}\text { Mean Tree } \\
\text { Height (m) }\end{array}$ & $\begin{array}{c}\text { Leaf Area } \\
\text { Index }\end{array}$ \\
\hline 10 & 106.74 & 26.52 & $1216.40 \pm 4.9$ & 18.79 & 8.20 & 1.57 \\
20 & 106.74 & 26.54 & $1174.44 \pm 4.9$ & 25.22 & 13.53 & 1.44 \\
40 & 106.74 & 26.51 & $1174.65 \pm 4.9$ & 36.06 & 21.89 & 1.45 \\
60 & 106.74 & 26.52 & $1183.08 \pm 4.9$ & 36.65 & 23.63 & 1.46 \\
\hline
\end{tabular}

\subsection{Sample Analysis}

After the soil dried naturally, stone, roots, leaves, and other material were removed prior to grinding and screening. Soil bulk density (BD) was determined by the ring-knife method and the soil water content (SW) were measured by the drying method; soil pH was determined by the 1:2.5 water immersion potential method; soil total nitrogen (TN) and available nitrogen (AN) were measured by an elemental analyser (CleverChem380P, Germany); total phosphorus (TP) and available phosphorus (AP) were measured by molybdenum-antimony colorimetric method; total potassium (TK) and available potassium (AK) were measured using a flame photometer; potential of hydrogen $(\mathrm{pH})$ was determined by potentiometric method; and soil organic carbon (SOC) was heated using potassium dichromate [26]. Leaf area index (LAI) was measured using HemiView that mainly consisted of a self-levelling mount, camera (Canon 80D), and HemiView canopy analysis software (Delta-T devices Ltd., Cambridge, UK). The procedure and method of HemiView can be found in the study by Bao et al. [27].

\subsection{Data Processing}

The hierarchical clustering analysis and mapping of soil properties were conducted with SPSS 26.0 (SPSS Inc., Chicago, IL, USA). Redundancy analysis (RDA) was conducted using Canoco 5 software (Microcomputer Power, Clover Lane, Ithaca, NY, USA). RDA uses a polynomial regression to determine the relationship between the typical variable $(\mathrm{y})$ and the total variation percentage of another group of variables $(\mathrm{x})$. The calculation formula is as follows [28]:

$$
\begin{aligned}
& R_{d}\left(X ; W_{k}\right)=\lambda^{2}{ }_{k} R_{d}\left(X ; V_{k}\right) \\
& R_{d}\left(Y ; V_{k}\right)=\lambda^{2}{ }_{k} R_{d}\left(Y ; W_{k}\right)
\end{aligned}
$$

In formula (1), $R_{d}\left(X ; W_{k}\right)$ represents the percentage variation explained by typical variables in the first group that is repeatedly explained by typical variables in the second group, referred to as the redundancy measure of typical variables in the first group. In formula (2), $R_{d}\left(Y ; V_{k}\right)$ refers to the percentage variation explained by typical variables in the first group that is repeatedly interpreted by typical variables in the second group, referred to as the redundancy measure of typical variables in the first group; the size of the redundancy measure refers to the degree to which these two typical variables can explain each other's variation in the other group.

The iterative control strategy is adopted in cluster analysis that separates clusters from top to bottom to form nested clusters and optimizes the clustering step by step. According to the similarity criteria, the most similar parts are merged and the least similar parts are divided; "tree view" is used to represent the divided hierarchy classes.

SPSS 26.0 was used for statistical analysis. All data were tested for normality and homogeneity of variance before the statistical analysis and were expressed as the mean and standard deviation (SD). Two-factor analysis of variance (one-way ANOVA, $n=3, p<0.05$ ) and Pearson's correlation analysis were used to analyse the differences in soil nutrients and stoichiometry in different soil layers of different-aged forests $(p<0.05)$. Data were graphed using Originlab software. 


\section{Results}

\subsection{Soil Physical Properties}

In reference to Figure 2, there were significant differences in the mean $\mathrm{pH}$ values of the $0-60 \mathrm{~cm}$ space soils of the four forest ages $(p<0.05)$. The SW value at 40 years was significantly different from that at 60 years $(p<0.05)$; SW exhibited a trend of first decreasing, increasing, and then decreasing with the increase of forest age. There was no significant difference in BD among different ages $(p>0.05)$. The SW and BD increased with the depth of the soil layer. The SW of each forest age was as follows: the maximum SW of M of forest age was $21.68 \pm 3.455 \%$, followed by that of 10 and 20 years $(24.6 \pm 2.335 \%$ and $21.68 \pm 2.169 \%$, respectively), and the minimum SW of 60 years was $17.86 \pm 2.897 \%$. The BD of each forest age was as follows: the BD of 10 years was the maximum $1.4 \pm 0.064 \mathrm{~g} / \mathrm{cm}^{3}$, followed by that of 60 and 20 years was $1.38 \pm 0.113$ and $1.35 \pm 0.129 \mathrm{~g} / \mathrm{cm}^{3}$, respectively, and the minimum BD of 40 years was $1.32 \pm 0.096 \mathrm{~g} / \mathrm{cm}^{3}$.

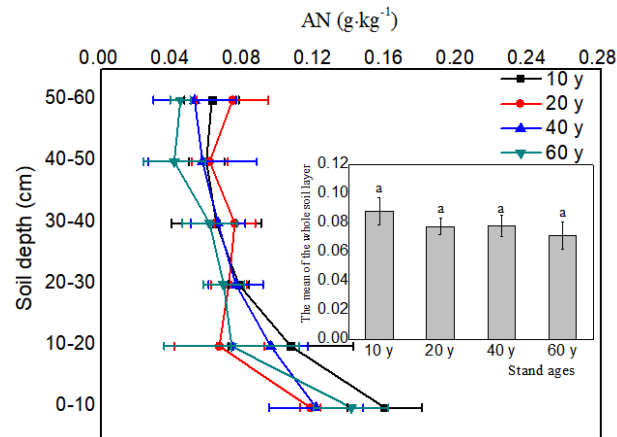

(A)

AK $\left(\mathrm{g} \cdot \mathrm{kg}^{-1}\right)$

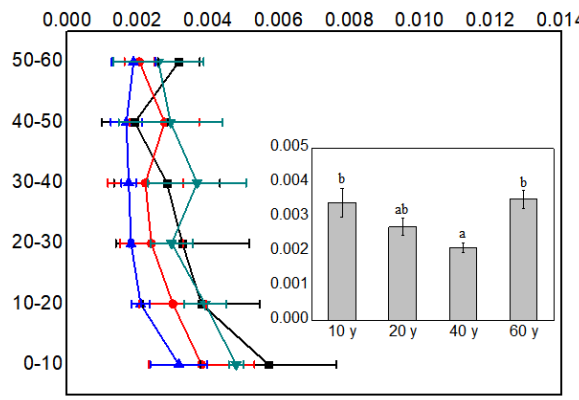

(C)

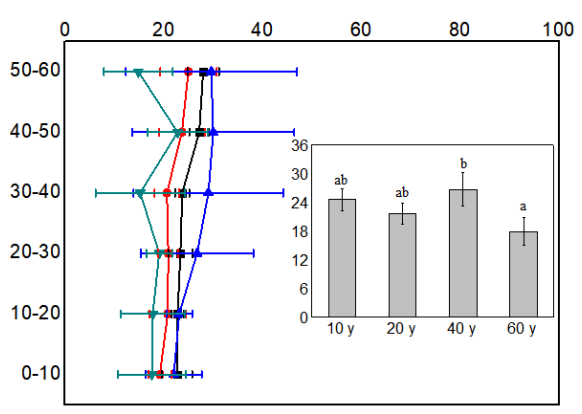

(E)

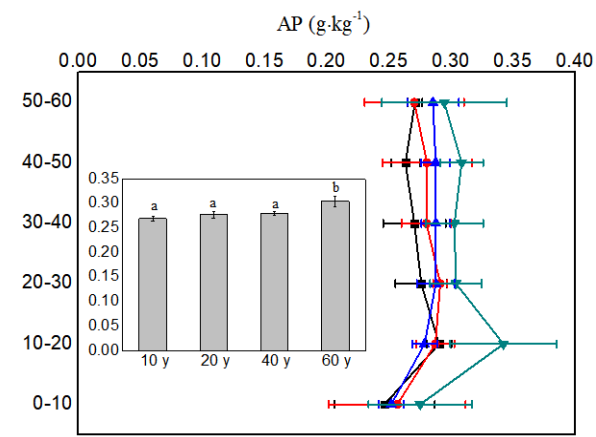

(B)

$\mathrm{pH}$

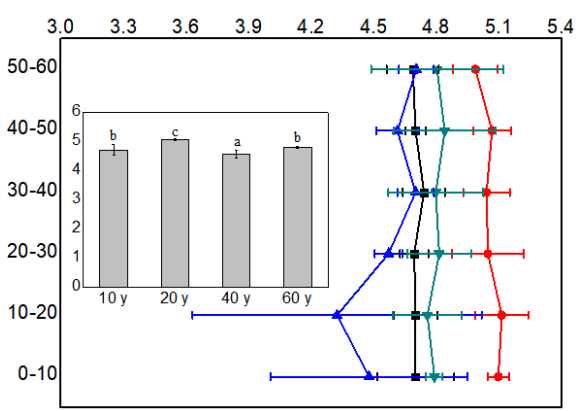

(D)

$\mathrm{BD}\left(\mathrm{g} \cdot \mathrm{cm}^{-3}\right)$

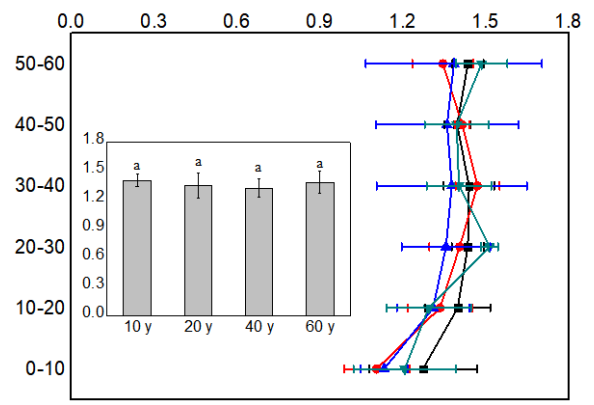

(F)

Figure 2. Physical and chemical properties of soil in Masson pine plantations of different ages. Different small letters indicate significant differences $(p<0.05)$. The histogram displays the average value from 0 to $60 \mathrm{~cm}$ and the curve shows the measured value from 0 to $60 \mathrm{~cm}$. AN, $\mathrm{AP}, \mathrm{AK}, \mathrm{SW}$, and $\mathrm{BD}$ represent soil available nitrogen, available phosphorus, available potassium, water content, and bulk density, respectively. (A-F) represents soil available nitrogen, available phosphorus, available potassium, $\mathrm{pH}$, water content and bulk density, respectively. 


\subsection{Soil Chemical Properties}

In reference to Figure 2, there was also a significant difference $(p<0.05)$ between the soil AP value of the 60-year-old Masson pine forest and the forests aged 10, 20, and 40 years, and the soil AP first increased and then decreased with the increase of forest age. The soil AP at 10, 20, 40, and 60-year forest ages was $0.31 \pm 0.061,0.47 \pm 0.365,0.24 \pm 0.020$, and $0.26 \pm 0.039 \mathrm{~g} / \mathrm{kg}$, respectively. There was a significant difference $(p<0.05)$ between the soil AK value at 40 years and that at 10, 20, and 60 years of age; AK first decreased and then increased with increasing forest age, while soil AK was $3.45 \pm 1.270,2.70 \pm 0.644$, $2.06 \pm 0.558$, and $3.48 \pm 0.812 \mathrm{~g} / \mathrm{kg}$ at $10,20,40$, and 60 -year forest ages, respectively. The $\mathrm{pH}$ value first increased and then decreased with increasing forest age. The $\mathrm{pH}$ value at 20 years was $5.07 \pm 0.438$ (the mean \pm standard deviation; the same below), followed by that at 60 years of age $(4.77 \pm 0.275), 10$ years $(4.80 \pm 0.126)$, and the lowest value of 40 years was $4.54 \pm 0.145$, all of which are acidic. There was no significant difference in the AN value among forest ages $(p>0.05)$. Soil AN decreased with the increase of forest age. Soil AN at 10, 20, 40, and 60 years of forest age was $87.76 \pm 38.88,77.18 \pm 20.28$, $77.40 \pm 25.93$, and $71.14 \pm 36.10 \mathrm{~g} / \mathrm{kg}$, respectively. Soil AN generally decreased with the depth of the soil layer with the maximum value appearing in the $0-10 \mathrm{~cm}$ soil layer. The soil AP and AK in different-aged forests did not change greatly with soil depth.

\subsection{Soil Stoichiometric Characteristics}

In reference to Table 2, we can observe that the soil C:N ratio was the highest at the age of 60 years, followed by that at 20 years and 40 years, whereas the 10 -year-old forest had the lowest C:N ratio. The soil C:N ratio at age 10 years was $47.40 \%, 12.07 \%$, and $50.33 \%$ lower than that of age 40,20, and 60 years, respectively. The soil C:P ratio decreased in the following order: 60 years, 40 years, 10 years, and 20 years. The soil C:P ratio at the age of 20 years was $3.37 \%, 23.04 \%$, and $48.58 \%$ lower than that of the 10,40 , and 60 -year-old forests, respectively. The soil N:P ratio was the highest at the age of 40 years, followed by that at ages of 60,10 , and 20 years. The soil N:P ratio at 20 years was $12.96 \%, 21.67 \%$, and $27.69 \%$ lower than that at 10,60 , and 40 years, respectively.

Table 2. Soil stoichiometric mean value in forests of different ages. C:N, C:P, and N:P represent the ratios of soil total organic carbon to total nitrogen, total organic carbon to total phosphorus, and total nitrogen to total phosphorus, respectively.

\begin{tabular}{cccl}
\hline Forest Age (Years) & C:N & C:P & N:P \\
\hline 10 & 160.02 & 91.52 & 0.54 \\
20 & 201.57 & 88.44 & 0.47 \\
40 & 181.99 & 114.91 & 0.65 \\
60 & 322.18 & 171.99 & 0.60 \\
\hline
\end{tabular}

Table 3 demonstrates that in the surface layer $(0-10 \mathrm{~cm})$, the soil organic carbon, total nitrogen, total phosphorus, and carbon-nitrogen ratio, the C:P ratio and N:P ratio in the 20-year-old forest were lower than those of the other three forest ages. The soil C:N ratio, C:P ratio, and N:P ratio of the 20-year-old forest were $4.05-25.04 \%, 47.87-65.52 \%$, and $43.94-64.08 \%$ lower than those of the other three forest ages (10, 40, and 60 years), respectively. The soil carbon in the Masson pine forests was the highest at the age of 60 years at $47.13 \pm 9.094 \mathrm{~g} / \mathrm{kg}$, followed by that at age 40,20 , and 10 years, and the soil carbon content was $27.13 \pm 9.631,25.73 \pm 9.407$, and $23.98 \pm 13.765 \mathrm{~g} / \mathrm{kg}$, respectively (Figure 3A). Soil stoichiometry did not change regularly with the soil layer, while the maximum C:N ratio and C:P ratio occurred in the 60-year-old Masson pine forest. There was no significant difference in N:P ratio among the four forest ages. 
Table 3. C:N ratio, C:P ratio, and N:P ratio in different-aged forests. The mean \pm standard deviation is shown in the table; $\mathrm{C}: \mathrm{N}, \mathrm{C}: \mathrm{P}$, and N:P represent the ratios of soil total organic carbon to total nitrogen, total organic carbon to total phosphorus, and total nitrogen to total phosphorus, respectively.

\begin{tabular}{ccccc}
\hline Soil Layer & Forest Age & C:N & C:P & N:P \\
\cline { 1 - 3 } $\mathbf{( c m )}$ & (Years) & & & \\
\cline { 1 - 3 } $0-10$ & 10 & $169.24 \pm 86.903$ & $111.08 \pm 0.080$ & $0.66 \pm 0.201$ \\
& 20 & $155.94 \pm 57.542$ & $57.91 \pm 0.399$ & $0.37 \pm 0.243$ \\
& 40 & $162.53 \pm 87.696$ & $167.96 \pm 0.049$ & $1.03 \pm 0.435$ \\
& 60 & $209.72 \pm 129.576$ & $166.45 \pm 0.025$ & $0.79 \pm 0.034$ \\
$10-20$ & 10 & $157.06 \pm 60.893$ & $94.25 \pm 0.066$ & $0.60 \pm 0.130$ \\
& 20 & $144.63 \pm 57.758$ & $61.25 \pm 0.183$ & $0.42 \pm 0.137$ \\
& 40 & $126.29 \pm 25.188$ & $82.44 \pm 0.042$ & $0.65 \pm 0.071$ \\
$20-30$ & 60 & $322.45 \pm 133.624$ & $189.79 \pm 0.021$ & $0.59 \pm 0.097$ \\
& 10 & $76.12 \pm 54.783$ & $40.68 \pm 0.072$ & $0.53 \pm 0.039$ \\
& 20 & $219.71 \pm 156.971$ & $142.19 \pm 0.082$ & $0.44 \pm 0.106$ \\
$30-40$ & 40 & $178.20 \pm 80.785$ & $91.21 \pm 0.039$ & $0.51 \pm 0.149$ \\
& 60 & $258.52 \pm 119.293$ & $149.28 \pm 0.052$ & $0.58 \pm 0.096$ \\
& 10 & $172.07 \pm 242.893$ & $94.11 \pm 0.094$ & $0.55 \pm 0.057$ \\
& 20 & $223.99 \pm 168.894$ & $24.19 \pm 1.555$ & $0.11 \pm 0.315$ \\
$40-50$ & 40 & $195.94 \pm 167.877$ & $122.63 \pm 0.067$ & $0.63 \pm 0.149$ \\
& 60 & $418.28 \pm 203.629$ & $233.99 \pm 0.017$ & $0.56 \pm 0.076$ \\
& 10 & $184.73 \pm 179.696$ & $59.17 \pm 0.123$ & $0.32 \pm 0.092$ \\
$50-60$ & 20 & $83.96 \pm 55.654$ & $45.27 \pm 0.080$ & $0.54 \pm 0.095$ \\
& 40 & $180.43 \pm 134.109$ & $73.81 \pm 0.021$ & $0.41 \pm 0.117$ \\
& 60 & $387.85 \pm 259.649$ & $169.04 \pm 0.007$ & $0.44 \pm 0.177$ \\
& 10 & $167.33 \pm 73.636$ & $42.32 \pm 0.138$ & $0.25 \pm 0.186$ \\
& 20 & $107.50 \pm 212.540$ & $112.29 \pm 0.026$ & $1.04 \pm 1.012$ \\
& 40 & $234.10 \pm 33.513$ & $133.03 \pm 0.053$ & $0.57 \pm 0.277$ \\
& 60 & $320.54 \pm 104.394$ & $180.44 \pm 0.037$ & $0.56 \pm 0.150$ \\
\hline
\end{tabular}

Figure 3 demonstrates that there was a significant difference $(p<0.05)$ between the soil $C$ value at 60 years and that at 10,20, and 40 years, and there was a significant difference $(p<0.05)$ between the soil TK value at 10 years and that at 20,40, and 60 years. Soil C, $\mathrm{TN}$, and TK first decreased and then increased with increasing forest age, and soil TP first increased and then decreased with increasing forest age. In general, soil C, TN, and TP decreased with increasing soil depth. In the $0-60 \mathrm{~cm}$ layer, the soil TN content of each forest age increased with the increase of forest age, and the TN content of 10, 20, 40, and 60 years of forest age was $87.75 \pm 38.883,77.18 \pm 20.285,77.00 \pm 25.939$, and $71.14 \pm 36.100 \mathrm{~g} / \mathrm{kg}$, respectively. The maximum TK of each forest age was $5.92 \pm 1.078 \mathrm{~g} / \mathrm{kg}$ at 10 years of forest age, followed by $3.37 \pm 0.883$ and $2.78 \pm 0.371 \mathrm{~g} / \mathrm{kg}$ at 40 and 60 years, respectively, and the minimum TK at 20 years was $2.46 \pm 0.444 \mathrm{~g} / \mathrm{kg}$. The average value of TP in the four forest soils was the highest at 20 years, followed by that at 10, 60, and 40 years; the average value of TK was the highest at 10 years, followed by that at 40,60 , and 20 years.

\subsection{Correlational Analyses of Soil Chemometrics}

In reference to Figure 4, regression analysis of TN and TP against C:N, C:P, and $\mathrm{N}: \mathrm{P}$ demonstrated that $\mathrm{C}: \mathrm{N}$ decreased with increasing $\mathrm{N}$ and $\mathrm{P}$ contents, that $\mathrm{C}: \mathrm{N}$ and $\mathrm{N}$ demonstrated exponential functional relationships, and that $\mathrm{P}$ demonstrated logarithmic functional relationships. C:P was negatively correlated with the $\mathrm{N}$ and $\mathrm{P}$ contents. There was a positive correlation between the N:P ratio and N content, the relation between them is $y=8.9114 x^{2}-0.7348 x+0.4269, R^{2}=0.6867$. 


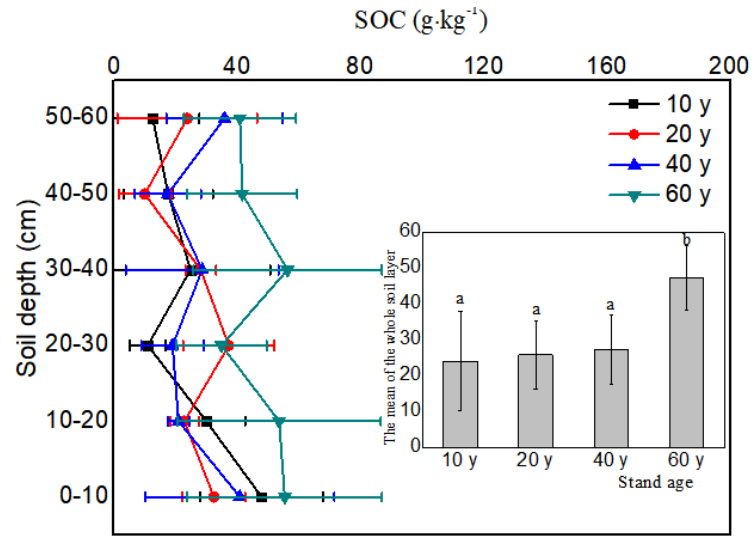

(A)

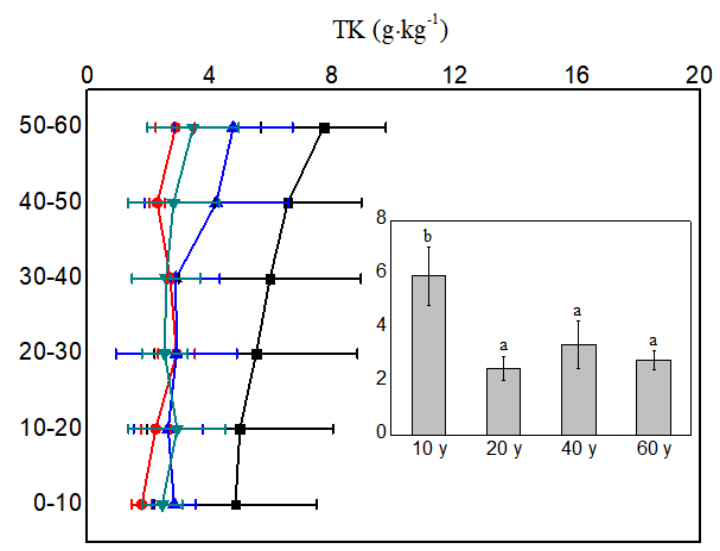

(C)

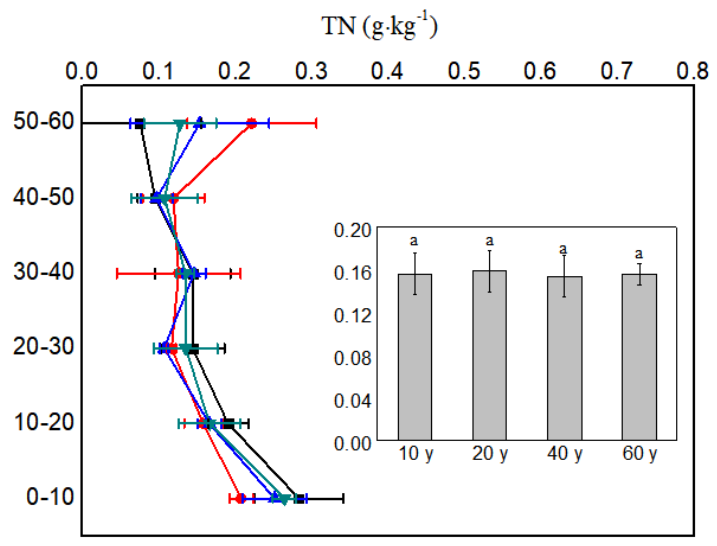

(B)

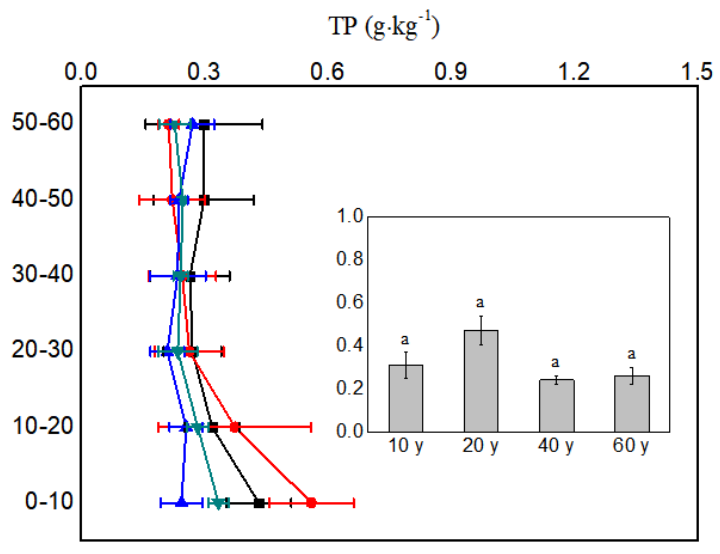

(D)

Figure 3. Content of soil organic carbon, total nitrogen, total phosphorus, and total potassium in different-aged forests. Different small letters indicate significant differences $(p<0.05)$. The histogram displays the average value from 0 to $60 \mathrm{~cm}$ and the curve shows the measured value from 0 to $60 \mathrm{~cm}$. SOC, TN, TK, and TP represent soil organic carbon, total nitrogen, total potassium, and total phosphorus, respectively. (A-D) represents soil organic carbon, total nitrogen, total potassium, and total phosphorus, respectively.

As observed from Table 4, TN was positively correlated with AN and AK and negatively correlated with AP and BD. There was no significant correlation between TP and each index. TK was positively correlated with SW. There was a significant positive correlation between TK and $\mathrm{AK}$, and TK and AP exhibited a significant negative correlation. $\mathrm{AN}$ and AK exhibited highly significant positive correlations, and AN and BD exhibited highly significant negative correlations. AP and SW exhibited highly significant negative correlations, and SW and BD exhibited highly significant negative correlations.

As observed from Figure 5A, the cluster analysis of the indicators of different-aged forests demonstrated that C:P and DBH were grouped together; $\mathrm{C}: \mathrm{P}$ and $\mathrm{C}: \mathrm{N}$ were grouped together; $\mathrm{C}: \mathrm{N}, \mathrm{C}: \mathrm{P}$, and $\mathrm{pH}$ were grouped together; and the other soil physical and chemical indexes were all self-contained. As observed from Figure 5B, through detrended correspondence analysis (DCA) of the soil quality principal component of different forest ages, SW, $\mathrm{pH}, \mathrm{TK}$, and $\mathrm{BD}$ were negatively correlated with $\mathrm{C}: \mathrm{N}, \mathrm{C}, \mathrm{DBH}$, and TN; $\mathrm{C}: \mathrm{N}$ and $\mathrm{N}: \mathrm{P}$ were negatively correlated with TP, AN, AP, AK, and LAI; and in general, C:P, C, C:N, SW, and TK had strong effects on soil quality. 


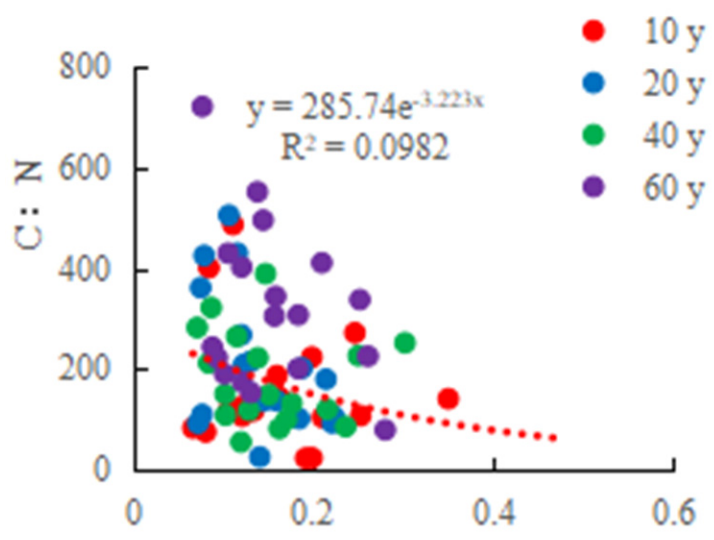

(A)

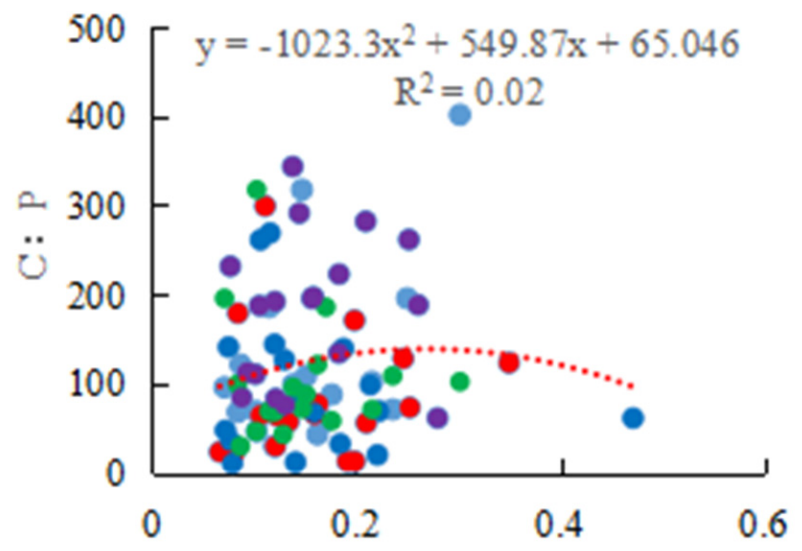

(C)

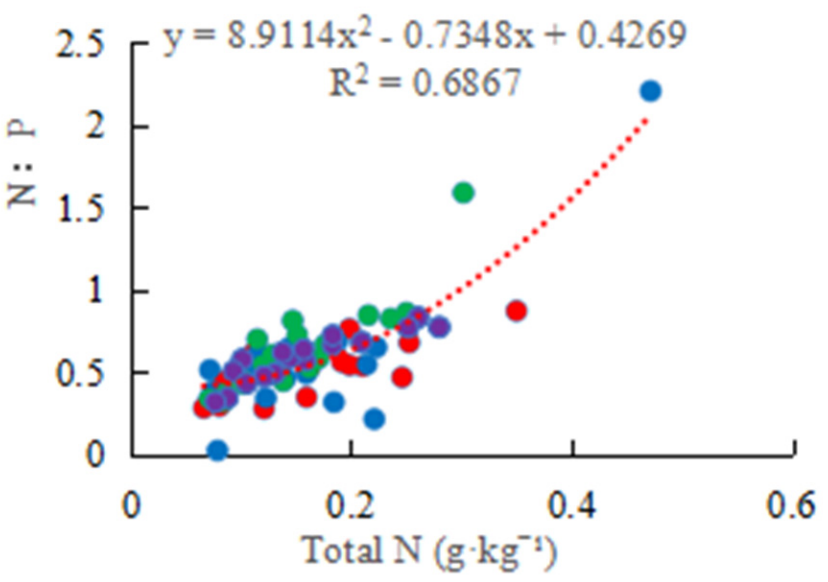

(E)

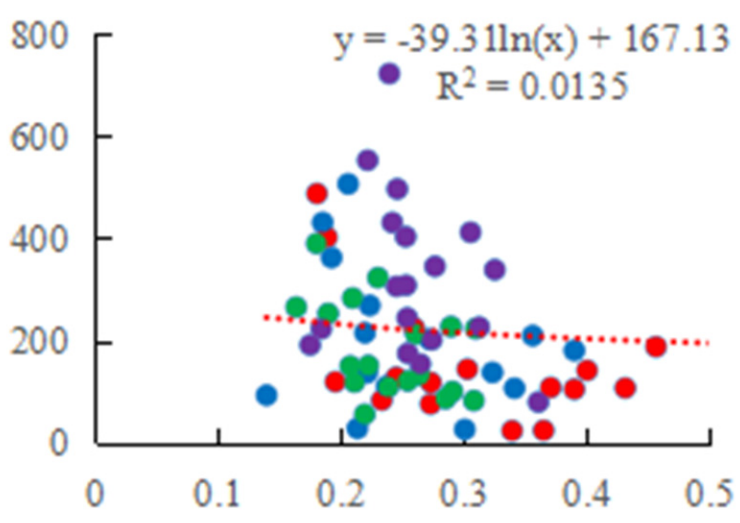

(B)

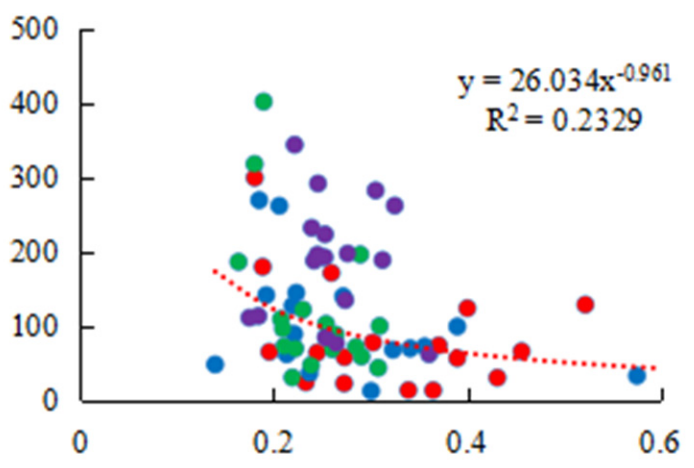

(D)

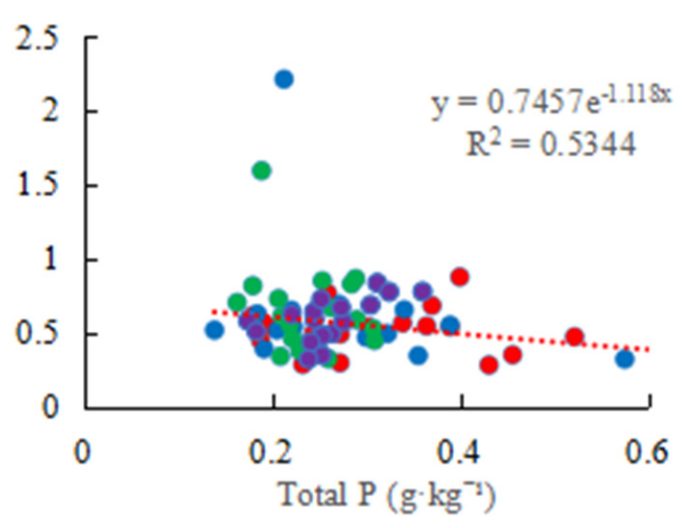

(F)

Figure 4. Relationships between soil chemometrics in different-aged forests. The graphs represent (A-F) the ordinate of two identical; (A,C,E) between the same abscissa; and (B,D,F) between the abscissa of the same. C:N, C:P, and N:P represent the ratios of soil total organic carbon to total nitrogen, total organic carbon to total phosphorus, and total nitrogen to total phosphorus, respectively. 
Table 4. Correlations between soil chemometrics in different-aged forests (TN, TP, TK, AN, AP, AK, SW, BD, and SOC represent soil total nitrogen, total phosphorus, total potassium, available nitrogen, available phosphorus, available potassium, water content, bulk density, and soil organic carbon, respectively).

\begin{tabular}{|c|c|c|c|c|c|c|c|c|c|c|}
\hline Index & TN & TP & TK & AN & AP & AK & SW & BD & $\mathrm{pH}$ & SOC \\
\hline $\mathrm{TN}$ & 1.000 & & & & & & & & & \\
\hline $\mathrm{TP}$ & 0.011 & 1.000 & & & & & & & & \\
\hline TK & -0.016 & -0.004 & 1.000 & & & & & & & \\
\hline AN & $0.626^{* *}$ & 0.123 & -0.023 & 1.000 & & & & & & \\
\hline $\mathrm{AP}$ & $-0.325^{* *}$ & -0.088 & -0.258 * & -0.294 * & 1.000 & & & & & \\
\hline $\mathrm{AK}$ & $0.460 * *$ & 0.097 & $0.250 *$ & $0.484^{* *}$ & $-0.239 *$ & 1.000 & & & & \\
\hline SW & 0.054 & 0.022 & $0.435^{* *}$ & 0.026 & $-0.347^{* *}$ & -0.122 & 1.000 & & & \\
\hline $\mathrm{BD}$ & $-0.367^{* *}$ & -0.038 & 0.086 & $-0.448^{* *}$ & $0.280 *$ & -0.149 & $-0.403^{* *}$ & 1.000 & & \\
\hline $\mathrm{pH}$ & 0.047 & 0.221 & -0.156 & -0.092 & -0.148 & 0.199 & -0.058 & -0.023 & 1.000 & \\
\hline SOC & 0.297 * & 0.004 & -0.183 & 0.173 & -0.019 & 0.196 & -0.104 & -0.164 & 0.091 & 1.000 \\
\hline
\end{tabular}

** indicates a significant correlation at the 0.01 level. * indicates a significant correlation at the 0.05 level.

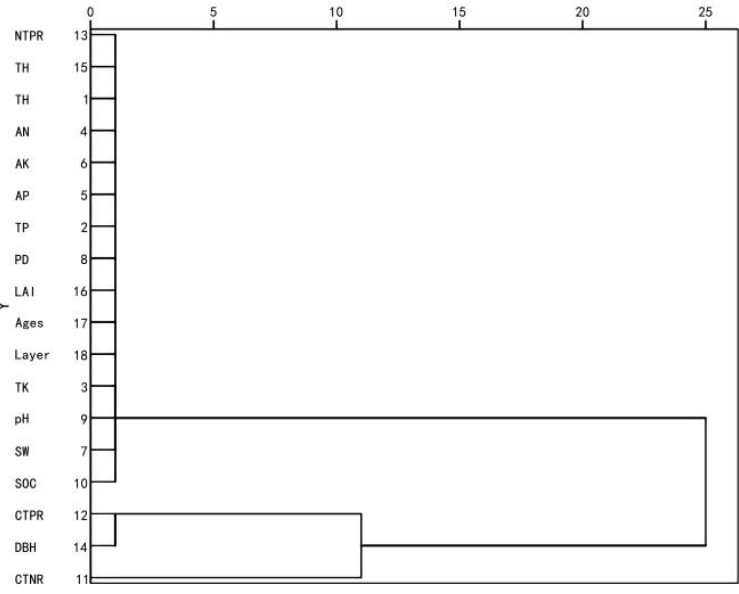

(A)

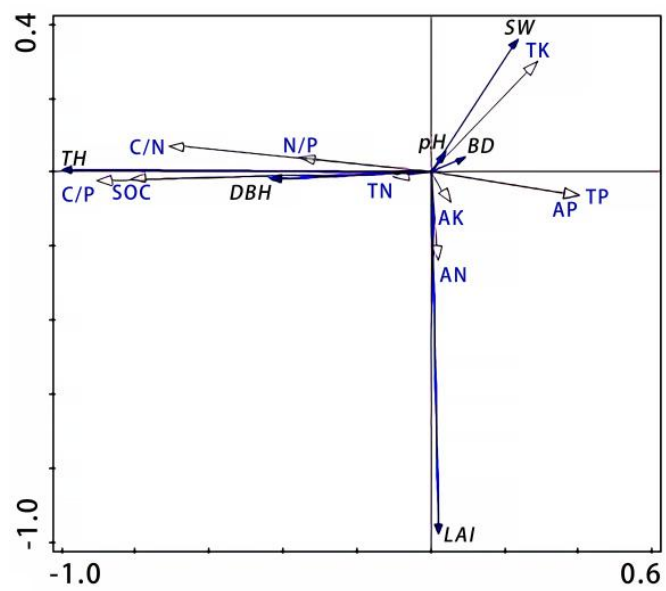

(B)

Figure 5. Hierarchical cluster tree (A) and redundancy analysis (B) of the physical and chemical properties of soil at different forest ages. TN, TP, TK, AN, AP, AK, SW, BD, and SOC represent soil total nitrogen, total phosphorus, total potassium, available nitrogen, available phosphorus, available potassium, water content, bulk density, and soil organic carbon, respectively.

\section{Discussion}

\subsection{Effect of Forest Age on Soil Physical Properties}

Soil physical properties are an important index to reflect the soil structure and hydrological status and to evaluate soil quality. The quality of soil physical properties will directly or indirectly affect soil aeration, water permeability, and soil fertility [29]. Studies have shown that forest age has a significant impact on the physical properties of soil. An increase in forest age can reduce the bulk density of the $0-40 \mathrm{~cm}$ soil layer and improve the soil porosity [30]. A similar result was obtained in this experiment regarding the increase in forest age as the soil bulk density gradually decreased in the $0-50 \mathrm{~cm}$ soil layer. There are two reasons for this: On the one hand, as time progresses, the alternation of root growth and senescence (root pores will be produced during root growth and organic matter will be produced during senescence) will cause the soil to become looser and have better air and water permeability. On the other hand, the bulk density decreases with the increase of soil layer due to the accumulation of litter layer beneath the forest over time [31]. In this experiment, there was no significant difference in the bulk density of Masson pine at different ages that may be because of the small difference in soil compaction at different 
ages due to the tending measures implemented during the growth period that affected the development of the soil structure [31].

Many studies have shown that a change in soil water is the result of natural and man-made activities such as the age of plants and land-use patterns. The soil water-holding capacity plays an important role in the growth of trees [32-35]. A study demonstrated that with increasing forest age, the soil water-holding capacity increased [36] because soil and water permeability gradually increase with increasing forest age. The soil and water permeability of overmature forests are the highest which is conducive to water infiltration and can effectively alleviate surface runoff and promote water conservation [37]. In this experiment, the change in the water content with forest age was different from that which is reported in other research. With increasing forest age, the water content first decreased, increased, and then decreased. This may be due to the rapid growth of trees in the early stage of afforestation that requires more water from the soil for tree growth. At intermediate forest ages, material exchange between soil organisms and the external environment occurs frequently due to tree growth and metabolism [38-40]. In the mature forest period, soil porosity is high [41]. In the current study, the difference in the canopy leaf area index (LAI) of different-aged forests may also be one of the reasons for the change in the water content. With increasing forest age, the canopy leaf area gradually increases and rainfall interception by the canopy also increases which leads to a decrease in the amount of rain that reaches the soil. In intermediate forest stages, the canopy enlarges, the evaporation of soil water decreases, the soil water conservation capacity is enhanced, and the soil water content increases. In the mature stage, the rainfall interception capacity of the canopy and litter layer increases which leads to a decrease in the soil moisture content [42,43].

\subsection{Effect of Forest Age on Soil Chemical Properties}

Previous studies on different-aged Masson pine plantations (5, 14, and 39 years) and Chinese fir plantations (10, 20, and 30 years) demonstrated that the soil organic carbon and total nitrogen contents increased with increasing forest age [44,45]. Luyssaert et al. [46] also reported a positive correlation between soil organic carbon accumulation and forest age. Soil carbon and nitrogen mainly originate from the return of litter. These elements first accumulate in the surface layer and then migrate and diffuse downward through leaching. In this study, with the increase in forest age, both organic carbon and total nitrogen first decreased and then increased. This result may be because in the young forest stage, the forest canopy is being built; there is low net productivity, high return, high absorption, and the shortest turnover time of soil nutrients due to the high density of the stand. In the intermediate forest stage, the net productivity of the stand increases markedly, biomass accumulates greatly, litter return decreases, and high amounts of soil nutrients are absorbed with low nutrient return to the soil, resulting in a decrease in the contents of soil carbon and nitrogen. In the mature forest, the soil carbon and nitrogen contents exhibited an increasing trend due to the decreased growth rate of the trees, the low tree density, limited litter return, and relatively low absorption and return of soil nutrients that are conducive to the accumulation of soil nutrients in forests [47,48].

Soil $\mathrm{pH}$ is a major factor directly related to soil quality. At present, there are different reports on the impact of forest age on soil $\mathrm{pH}$. Some studies have pointed out that the $\mathrm{pH}$ value increases significantly with increasing forest age [49]; other studies have reported that the soil $\mathrm{pH}$ value gradually decreases with increasing forest age and there is a trend of soil acidification. In this experiment, the $\mathrm{pH}$ value first increased and then decreased with increasing forest age which may be related to ion absorption by the root system that occurs through the release of $\mathrm{H}^{+}$[50]. Simultaneously, the leaching of bases with water, atmospheric acid deposition, the accumulation of organic matter, and the respiration of soil microorganisms may lead to a decrease in the soil $\mathrm{pH}$ value $[50,51]$. There was no significant difference in the $\mathrm{pH}$ value between the young forest and mature forest which indicated that in the process of forest growth in the experimental area, forest age did not cause obvious acidification of the soil. Although the $\mathrm{pH}$ value of soil affects the 
availability of soil nutrients, there is no significant correlation between the $\mathrm{pH}$ value and soil nutrients [52]. The same results were obtained in this study. No significant correlation was found between $\mathrm{pH}$ and other soil nutrient indexes. Therefore, it can be concluded that $\mathrm{pH}$ affects soil nutrients indirectly by affecting root growth and soil microorganisms.

Soil phosphorus mainly originates from rock weathering. Phosphorus is the most insoluble mineral nutrient [53]. In this experiment, the total soil phosphorus first increased and then decreased with increasing forest age which is consistent with the change trend of the $\mathrm{pH}$ with increasing forest age that may be due to the acidic soil in South China. The availability of phosphorus will increase with the increasing $\mathrm{pH}$ because the solubility of iron phosphate and aluminium salt increases with increasing $\mathrm{pH}$. Simultaneously, soil phosphorus is also affected by the soil organic matter and nitrogen contents [54]. The soil total phosphorus value in the study area was low and the range is between $0.13-2.96 \mathrm{~g} / \mathrm{kg}$ that may be because the test area is located in the Guizhou Plateau area in Southwest China. The main source of phosphorus in this area is rock weathering. Most of the rock types are limestone and the weathering speed is very slow, resulting in a low content of phosphorus in the soil. Another possibility regarding the reason behind the low total phosphorus content in the soil is the slow vertical movement of soil nutrient elements due to the absorption of phosphorus by soil particles or the formation of insoluble phosphate [54]. The total potassium in the mature forest soil was significantly lower than that in the other forests that may be due to an increase in acidic matter in the soil and a decrease in root activity, leading to a decrease in plant potassium absorption.

In the 0-60 cm soil layer, the contents of organic carbon, total nitrogen, total phosphorus, available nitrogen, and available potassium of Masson pine plantations of different forest ages were the largest in the topsoil $(0-10 \mathrm{~cm})$ and all the indexes exhibited a general downward trend with the increase of soil depth that is consistent with other research $[55,56]$. This is because the input of soil carbon and nitrogen in Masson pine plantations mainly depends on the decomposition of surface litter, animal debris, and faeces that are mainly concentrated in the $0-10 \mathrm{~cm}$ soil layer [56] and then gradually move downward. The study area is a pure forest; undergrowth vegetation is rare or comprises individual species, the litter stock is low, and decomposition and transformation are slow, resulting in the decline of soil fertility. With an increase in forest age, although the litter decomposition rate increases, the forest soil nutrient content can be controlled [57]. It is of positive significance to promote the recycling of soil nutrients to adopt stand adjustment measures at the appropriate age stage to make the forest productivity gradually stabilize in the mature stage [57].

\subsection{Effect of Forest Age on Soil Chemometrics}

Soil stoichiometry is a new method to study soil nutrient cycling. Among the indicators, soil C:N reflects the level of soil fertility and decomposition rate of organic matter. In general, soils with lower $\mathrm{C}: \mathrm{N}$ ratios have better fertility and faster mineralization rates of $\mathrm{C}$ and $\mathrm{N}$ [58]. In this study, compared with the older Masson pine plantation, the younger plantation had a lower soil C: $\mathrm{N}$ ratio that may be related to the high input of $\mathrm{N}$ caused by the change in $\mathrm{N}$ cycling in the atmosphere. Soil C:P is used to measure the release potential of $\mathrm{P}$ from soil microbially mineralized organic matter. A lower C:P value indicates a higher availability of soil P [45]. The soil C:P ratio of the different-aged Masson pine plantations in this study area was 119.54, which was similar to the results of other studies [59]. The threshold of the soil C:P ratio is 200; when the value is higher than 200, P is mainly fixed in the soil, and when the value is lower than 200, soil microbial C increases. P mainly undergoes net mineralization [46]. In this study, the soil C:P ratio in the four forests was ranked as follows: 60 years $>40$ years $>10$ years $>20$ years, and the value of the soil C:P ratio of the four forests was less than 200 , indicating that in this study area with the increase in forest age, $\mathrm{P}$ mainly undergoes net mineralization. The availability of $\mathrm{P}$ was higher in the younger forest that may be due to the increasing $\mathrm{P}$ demand for aboveground growth with the increase in forest age. 
The soil N:P ratio is an important indicator of $\mathrm{N}$ supply $[60,61]$. In this study, the soil $\mathrm{N}: \mathrm{P}$ ratio in the four forests was ranked as follows: 40 years $>60$ years $>10$ years $>20$ years. On the whole, the soil $C: N, C: P$, and $N: P$ ratios at the age of 20 years were lower than those of the other three forest ages (i.e., 10, 40, and 60 years old), indicating that the soil fertility in the intermediate forest stage was higher. In this study, the soil C:P (i.e., 119.54) and N:P (i.e., 0.57) ratios measured in the Masson pine plantations were quite different from those of the global natural forest ecosystems (i.e., C:P (81.9) and N:P (6.6) [24]; this is because there is an abundance of gravel in the soil beneath the Masson pine plantations in Southwest China and because the weathering rate of the parent material is low which leads to the slow mineralization of soil P. Therefore, the soil P content is low in the Masson pine plantations [61], leading to the imbalance of $\mathrm{N}$ and $\mathrm{P}$ that affects the growth and development of trees, the material, and energy cycling of the ecosystem. According to Walker and Syers [62], nutrient concentrations are highest in young soils but decrease during soil formation because nutrients are lost during leaching (converted into forms that plants cannot obtain such as phosphorus) at a faster rate than they are replenished from parent materials [63]. In the tropical montane rainforests in Mount Kinabalu, Borneo, researchers found that soil nutrient availability decreased with soil age and soil nutrient limitation has adverse effects on tree growth [64]. No species [65] can use light and nutrients efficiently for a long time. Therefore, to ensure a high harvest index of Masson pine plantations, higher inputs of $\mathrm{N}$ and especially $\mathrm{P}$ are needed. We aimed to establish a simple conceptual model to describe the relationship between soil nutrient contents and stoichiometry. The conceptual model demonstrates that C:N decreases with increasing $\mathrm{P}$ content; that the relationship between $\mathrm{C}: \mathrm{N}$ and $\mathrm{N}$ is exponential; the relationship between $\mathrm{C}: \mathrm{N}$ and $\mathrm{P}$ is logarithmic; and the relationship between $\mathrm{C}: \mathrm{P}$ and $\mathrm{N}$ is negative. This reveals that there is antagonism between elements.

\section{Conclusions}

The age of Masson pine forests has a significant effect on soil physical and chemical indexes and the level of soil fertility. With the increase in plantation age, the total nitrogen first decreased and then increased, and the total phosphorus content first increased and then decreased. The soil stoichiometric values at the age of 20 years were lower than those at other forest ages. The intermediate forest age is the optimal period for soil nutrient regulation and the improvement of soil properties can achieve the best results in this period. With increasing soil depth, the values of soil organic carbon, total nitrogen, total phosphorus, available nitrogen, and available potassium decreased, while the soil moisture and bulk density increased, and the maximum values were measured in the 50-60 cm soil layer. There was a significant non-linear correlation between the stoichiometric ratio, nitrogen, and phosphorus in the soil. In the growth process of Masson pine, soil organic carbon and total nitrogen are the main factors that control the soil ecostoichiometric ratios. Considering this study area as a reference, to ensure the sustainable supply of soil nutrients for the growth of Masson pine and to improve soil quality, higher inputs of nitrogen and especially phosphorus are necessary in the intermediate stage of forest growth. The results of this study are beneficial to improve the sustainability of Masson pine plantation production, further study the relationship between soil stoichiometry and forest age, and provide a basis for the protection and management of plantations.

Author Contributions: Conceptualization, L.Z. and X.Y.; methodology, X.Y.; software, Q.F.; validation, L.Z. and G.D.; formal analysis, X.Y.; investigation, X.Y. and Q.F.; resources, L.Z.; data curation, L.Z. and X.Y.; writing—original draft preparation, X.Y.; writing—review and editing, L.Z. and X.Y.; visualization, L.Z.; supervision, L.Z.; project administration, L.Z.; funding acquisition, L.Z. All authors have read and agreed to the published version of the manuscript.

Funding: This This work was financially supported by the National Natural Science Foundation of China (41867014), the Project for Talented Young Scientists of Guizhou Province of China (QKHPTRC [2019]5671; QJHKYZ[2021]025), the China Postdoctoral Science Foundation (2020M670527), the 
Guizhou Province Graduate Research Fund (YJSCXJH[2020]067), and the First-class Discipline Construction Project in Guizhou Province (GNYL[2017]007).

Conflicts of Interest: The authors declare no conflict of interest.

\section{References}

1. Pötzelsberger, E.; Hasenauer, H. Soil change after 50years of converting Norway spruce dominated age class forests into single tree selection forests. For. Ecol. Manag. 2015, 338, 176-182. [CrossRef]

2. Jobbágy, E.G.; Jackson, R.B. The uplift of soil nutrients by plants: Biogeochemical consequences across scales. Ecology 2004, 85, 2380-2389. [CrossRef]

3. Céspedes-Payret, C.; Piñeiro, G.; Gutiérrez, O.; Panario, D. Land use change in a temperate grassland soil: Afforestation effects on chemical properties and their ecological and mineralogical implications. Sci. Total Environ. 2012, 438, 549-557. [CrossRef] [PubMed]

4. Temesgen, D.; Gonzálo, J.; Turrión, M.B. Effects of short-rotation Eucalyptus plantations on soil quality attributes in highly acidic soils of the central highlands of Ethiopia. Soil Use Manag. 2016, 32, 210-219. [CrossRef]

5. López, D.M.S.; Arturi, M.F.; Goya, J.F.; Pérez, C.; Frangi, J.L. Eucalyptus grandis plantations: Effects of management on soil carbon, nutrient contents and yields. J. For. Res. 2018, 31, 601-611. [CrossRef]

6. Gonc alves, J.L.M.; Stape, J.L.; Laclau, J.P.; Smethurst, P.; Gava, J.L. Silvicultural effects on the productivity and wood quality of eucalypt plantations. For. Ecol. Manag. 2004, 193, 45-61. [CrossRef]

7. Graham, M.H.; Haynes, R.J. Organic matter accumulation and fertilizer-induced acidification interact to affect soil microbial and enzyme activity on a long-term sugarcane management experiment. Biol. Fertil. Soils 2005, 41, 249-256. [CrossRef]

8. Lucas-Borja, M.E.; de Santiago, J.H.; Yang, Y.; Shen, Y.; Candel-Pérez, D. Nutrient, metal contents and microbiological properties of litter and soil along a tree age gradient in Mediterranean forest ecosystems. Sci. Total Environ. 2019, 650, 749-758. [CrossRef]

9. Thomaes, A.; De Keersmaeker, L.; Van Calster, H.; De Schrijver, A.; Vandekerkhove, K.; Verstraeten, G.; Verheyen, K. Diverging effects of two contrasting tree species on soil and herb layer development in a chronosequence of post-agricultural forest. For. Ecol. Manag. 2012, 278, 90-100. [CrossRef]

10. Zechmeister-Boltenstern, S.; Keiblinger, K.M.; Mooshammer, M.; Penuelas, J.; Richter, A.; Sardans, J.; Wanek, W. The application of ecological stoichiometry to plant-microbial-soil organic matter transformations. Ecol. Monogr. 2015, 85, 133-155. [CrossRef]

11. Yang, Y.; Liu, B. Effects of planting Caragana shrubs on soil nutrients and stoichiometries in desert steppe of Northwest China. Catena 2019, 183, 104213. [CrossRef]

12. Zhu, T.; Zeng, S.; Qin, H.; Zhou, K.; Yang, H.; Lan, F.; Huang, F.; Cao, J.; Müller, C. Low nitrate retention capacity in calcareous soil under woodland in the karst region of southwestern China. Soil Biol. Biochem. 2016, 97, 99-101. [CrossRef]

13. Yang, Y.S.; Guo, J.F.; Chen, G.S.; Xie, J.S.; Gao, R.; Li, Z.; Jin, Z. Litter production, seasonal pattern and nutrient return in seven natural forests compared with a plantation in southern China. Forestry 2005, 78, 403-415. [CrossRef]

14. Delgado-Baquerizo, M.; Reich, P.; Khachane, A.N.; Campbell, C.D.; Thomas, N.; Freitag, T.E.; Abu Al-Soud, W.; Sørensen, S.; Bardgett, R.D.; Singh, B.K. It is elemental: Soil nutrient stoichiometry drives bacterial diversity. Environ. Microbiol. 2017, 19, 1176-1188. [CrossRef] [PubMed]

15. Yang, Y.; Liu, B.-R.; An, S.-S. Ecological stoichiometry in leaves, roots, litters and soil among different plant communities in a desertified region of Northern China. Catena 2018, 166, 328-338. [CrossRef]

16. Lucas-Borja, M.; Hedo, J.; Cerdá, A.; Candel-Pérez, D.; Viñegla, B. Unravelling the importance of forest age stand and forest structure driving microbiological soil properties, enzymatic activities and soil nutrients content in Mediterranean Spanish black pine(Pinus nigra Ar. ssp. salzmannii) Forest. Sci. Total Environ. 2016, 562, 145-154. [CrossRef]

17. Jonard, M.; Nicolas, M.; Coomes, D.A.; Caignet, I.; Saenger, A.; Ponette, Q. Forest soils in France are sequestering substantial amounts of carbon. Sci. Total Environ. 2017, 574, 616-628. [CrossRef]

18. Leuschner, C.; Wulf, M.; Bäuchler, P.; Hertel, D. Forest Continuity as a Key Determinant of Soil Carbon and Nutrient Storage in Beech Forests on Sandy Soils in Northern Germany. Ecosystems 2014, 17, 497-511. [CrossRef]

19. Bautista-Cruz, A.; del Castillo, R.F.; Etchevers, J.D.; Gutiérrez-Castorena, M.D.C.; Baez, A. Selection and interpretation of soil quality indicators for forest recovery after clearing of a tropical montane cloud forest in Mexico. For. Ecol. Manag. 2012, 277, 74-80. [CrossRef]

20. Pommerening, A.; Murphy, S.T. A review of the history, definitions and methods of continuous cover forestry with special attention to afforestation and restocking. Forestry 2004, 77, 27-44. [CrossRef]

21. Spiecker, H.; Hansen, J.; Klimo, E.; Skovsgaard, J.P.; Sterba, H.; von Teuffel, K. (Eds.) Norway Spruce Conversion-Options and Consequences; European Forest Institute Research Report; Brill Academic Pub.: Boston, MA, USA; Köln, Germany, 2004.

22. Corwin, D.; Kaffka, S.; Hopmans, J.; Mori, Y.; Van Groenigen, J.W.; van Kessel, C.; Lesch, S.; Oster, J. Assessment and field-scale mapping of soil quality properties of a saline-sodic soil. Geoderma 2003, 114, 231-259. [CrossRef]

23. Li, H.; Crabbe, M.J.C.; Xu, F.; Wang, W.; Niu, R.; Gao, X.; Zhang, P.; Chen, H. Seasonal Variations in Carbon, Nitrogen and Phosphorus Concentrations and C:N:P Stoichiometry in the Leaves of Differently Aged Larix principis-rupprechtii Mayr. Plantations. Forests 2017, 8, 373. [CrossRef]

24. Justine, M.F.; Yang, W.; Wu, F.; Tan, B.; Khan, M.N.; Li, Z. Dissolved organic matter in soils varies across a chronosequence of Pinus massoniana plantations. Ecosphere 2017, 8, e01764. [CrossRef] 
25. Huang, Z.X. Effect of thinning on growth of Masson pine middle aged forest. For. Investig. Des. 2019, 39, 49-53.

26. Zederer, D.P.; Talkner, U.; Spohn, M.; Joergensen, R.G. Microbial biomass phosphorus and C/N/P stoichiometry in forest floor and A horizons as affected by tree species. Soil Biol. Biochem. 2017, 111, 166-175. [CrossRef]

27. Bao, Y.; Ni, W.; Wang, D.; Yue, C.; He, H.; Verbeeck, H. Effects of Tree Trunks on Estimation of Clumping Index and LAI from HemiView and Terrestrial LiDAR. Forests 2018, 9, 144. [CrossRef]

28. Makarenkov, V.; Legendre, P. Nonlinear redundancy analysis and canonical correspondence analysis based on polynomial regression. Ecology 2002, 83, 1146. [CrossRef]

29. Gairola, S.U.; Soni, P. Role of soil physical properties in ecological succession of restored mine land-A case study. Int. J. Environ. Sci. 2010, 1, 475-480.

30. Yesilonis, I.; Szlavecz, K.; Pouyat, R.; Whigham, D.; Xia, L. Historical land use and stand age effects on forest soil properties in the Mid-Atlantic US. For. Ecol. Manag. 2016, 370, 83-92. [CrossRef]

31. Sutinen, R.; Pänttäjä, M.; Teirilä, A.; Sutinen, M.-L. Effect of mechanical site preparation on soil quality in former Norway spruce sites. Geoderma 2006, 136, 411-422. [CrossRef]

32. Skubel, R.; Arain, M.A.; Peichl, M.; Brodeur, J.; Khomik, M.; Thorne, R.; Trant, J.; Kula, M. Age effects on the water-use efficiency and water-use dynamics of temperate pine plantation forests. Hydrol. Process. 2015, 29, 4100-4113. [CrossRef]

33. Sperry, J.S.; Hacke, U.G.; Oren, R.; Comstock, J.P. Water deficits and hydraulic limits to leaf water supply. Plant Cell Environ. 2002, 25, 251-263. [CrossRef]

34. Chaves, M.M.; Maroco, J.P.; Pereira, J.S. Understanding plant responses to drought-from genes to the whole plant. Funct. Plant Biol. 2003, 30, 239-264. [CrossRef]

35. Bréda, N.; Huc, R.; Granier, A.; Dreyer, E. Temperate forest trees and stands under severe drought: A review of ecophysiological responses, adaptation processes and long-term consequences. Ann. For. Sci. 2006, 63, 625-644. [CrossRef]

36. Dixon-Coppage, T.L.; Davis, G.L.; Couch, T.; Brevik, E.C.; Barineau, C.I.; Vincent, P.C. A forty-year record of carbon sequestration in an abandoned borrow-pit, Lowndes County, GA. Soil Crop. Sci. Soc. Fla. Proc. 2005, 64, 8-15.

37. Bastida, F.; Zsolnay, A.; Hernandez, T.; García, C. Past, present and future of soil quality indices: A biological perspective. Geoderma 2008, 147, 159-171. [CrossRef]

38. Nan, W.; Ta, F.; Meng, X.; Dong, Z.; Xiao, N. Effects of age and density of Pinus sylvestris var. mongolica on soil moisture in the semiarid Mu Us Dunefield, northern China. For. Ecol. Manag. 2020, 473, 118313. [CrossRef]

39. Tian, A.; Wang, Y.; Webb, A.A.; Liu, Z.; Ma, J.; Yu, P.; Wang, X. Water yield variation with elevation, tree age and density of larch plantation in the Liupan Mountains of the Loess Plateau and its forest management implications. Sci. Total Environ. 2021, 752, 141752. [CrossRef]

40. Zhang, Z.M.; Zhou, Y.C.; Huang, X.F. Factors Influencing the Evolution of Human-driven Rocky Desertification in Karst Areas. Land Degrad. Dev. 2020, 31, 2506-2513. [CrossRef]

41. Lozano-García, B.; Parras-Alcántara, L.; Brevik, E.C. Impact of topographic aspect and vegetation (native and reforested areas) on soil organic carbon and nitrogen budgets in Mediterranean natural areas. Sci. Total Environ. 2016, 544, 963-970. [CrossRef]

42. Chen, W.; Li, Z.; Jiao, L.; Wang, C.; Gao, G.; Fu, B. Response of Soil Moisture to Rainfall Event in Black Locust Plantations at Different Stages of Restoration in Hilly-gully Area of the Loess Plateau, China. Chin. Geogr. Sci. 2020, 30, 427-445. [CrossRef]

43. Zema, D.A.; Plaza-Alvarez, P.A.; Xu, X.; Carra, B.G.; Lucas-Borja, M.E. Influence of forest stand age on soil water repellency and hydraulic conductivity in the Mediterranean environment. Sci. Total Environ. 2021, 753, 142006. [CrossRef]

44. Daping, W.; Jian, Z.; Danju, Z.; Chuanbei, L.; Yanbo, Z.; Jie, Z. Leaf carbon, nitrogen, and phosphorus resorption and the stoichiometry in Pinus massoniana plantations with various canopy densities. Chin. J. Appl. Environ. Biol. 2017, 23, 560-569.

45. Pan, P.; Zhao, F.; Ning, J.; Zhang, L.; Ouyang, X.; Zang, H. Impact of understory vegetation on soil carbon and nitrogen dynamic in aerially seeded Pinus massoniana plantations. PLoS ONE 2018, 13, e0191952. [CrossRef]

46. Luyssaert, S.; Schulze, E.D.; Börner, A.; Knohl, A.; Hessenmöller, D.; Law, B.; Ciais, P.; Grace, J. Old-growth forests as global carbon sinks. Nature 2008, 455, 213-215. [CrossRef]

47. Montfort, F.; Nourtier, M.; Grinand, C.; Maneau, S.; Mercier, C.; Roelens, J.-B.; Blanc, L. Regeneration capacities of woody species biodiversity and soil properties in Miombo woodland after slash-and-burn agriculture in Mozambique. For. Ecol. Manag. 2021, 488, 119039. [CrossRef]

48. Zhang, Z.; Huang, X.; Zhou, Y. Spatial heterogeneity of soil organic carbon in a karst region under different land use patterns. Ecosphere 2020, 11. [CrossRef]

49. Malchair, S.; Carnol, M. Microbial biomass and C and N transformation in forest floors under European beech, sessile oak, Norway spruce and Douglas-fir at four temperate forest sites. Soil Biol. Biochem. 2009, 41, 831-839. [CrossRef]

50. Hinsinger, P.; Jaillard, B. Root-induced release of interlayer potassium and vermiculitization of phlogopite as related to potassium depletion in the rhizosphere of ryegrass. Eur. J. Soil Sci. 1993, 44, 525-534. [CrossRef]

51. Wong, V.N.L.; Dalal, R.; Greene, R.S.B. Salinity and sodicity effects on respiration and microbial biomass of soil. Biol. Fertil. Soils 2008, 44, 943-953. [CrossRef]

52. Lin, Y.I.; Banjie, L.; Qiqing, Z. Correlation Between pH Value and Nutrients in Soil of the Tobacco-growing Areas of Sanming City in Fujian Province. Tob. Sci. Technol. 2017, 50, 24-30.

53. Faisal, N.K.; Martin, L.; Gordon, T.; Douglas, L.G. Elevated atmospheric $\mathrm{CO}_{2}$ changes phosphorus fractions in soils under a short rotation poplar plantation (EuroFACE). Soil Biol. Biochem. 2008, 40, 1716-1723. 
54. Jones, D.L.; Darrah, P.R. Role of root derived organic acids in the mobilization of nutrients from the rhizosphere. Plant Soil 1994, 166, 247-257. [CrossRef]

55. Fan, H.; Wu, J.; Liu, W.; Yuan, Y.; Hu, L.; Cai, Q. Linkages of plant and soil C:N:P stoichiometry and their relationships to forest growth in subtropical plantations. Plant Soil 2015, 392, 127-138. [CrossRef]

56. Deng, H.; Chen, A.; Yan, S.; Lin, Y.; Hong, W. Nutrient resorption efficiency and C:N:P stoichiometry in different ages of Leucaena leucocephala. Chin. J. Appl. Environ. Biol. 2015, 21, 522-527.

57. Yang, H.-X.; Wang, S.-L.; Fan, B.; Zhang, W.-D.; Wei, C.-E. Dynamics of nutrients in an age sequence of Pinus massoniana plantation. Chin. J. Appl. Ecol. 2010, 21, 1907-1914.

58. Tian, L.; Shi, W. Short-term effects of plant litter on the dynamics, amount, and stoichiometry of soil enzyme activity in agroecosystems. Eur. J. Soil Biol. 2014, 65, 23-29. [CrossRef]

59. Bengtsson, G.; Bengtson, P.; Månsson, K.F. Gross nitrogen mineralization-, immobilization-, and nitrification rates as a function of soil C/N ratio and microbial activity. Soil Biol. Biochem. 2003, 35, 143-154. [CrossRef]

60. Ren, S.-J.; Yu, G.-R.; Jiang, C.-M.; Fang, H.-J.; Sun, X.-M. Stoichiometric characteristics of leaf carbon, nitrogen, and phosphorus of 102 dominant species in forest ecosystems along the North-South Transect of East China. Chin. J. Appl. Ecol. 2012, $23,581$.

61. Tian, H.Q.; Chen, G.S.; Zhang, C.; Melillo, J.M.; Hall, C.A.S. Pattern and variation of C:N:P rations in China's soils: A synthesis of observational data. Biogeochemistry 2010, 98, 139-151. [CrossRef]

62. Walker, T.; Syers, J. The fate of phosphorus during pedogenesis. Geoderma 1976, 15, 1-19. [CrossRef]

63. Turner, B.L.; Condron, L.M. Pedogenesis, nutrient dynamics, and ecosystem development: The legacy of T.W. Walker and J.K. Syers. Plant Soil 2013, 367, 1-10. [CrossRef]

64. Aiba, S.-I.; Kitayama, K. Light and nutrient limitations for tree growth on young versus old soils in a Bornean tropical montane forest. J. Plant Res. 2020, 133, 665-679. [CrossRef]

65. Cody, M.L. Resources and Communities Resource Competition and Community Structure David Tilman. BioScience 1983, 33, 723-724. [CrossRef] 